\title{
From the invisible, the everyday and the unmentionable towards narrative strategies to explain, understand, remember. New Perspectives on Cultural Preservation.
}

\author{
Borsotti, Marco. \\ Department of Architecture and Urban Studies, Politecnico di Milano, Italy.marco.borsotti@polimi.it.
}

\begin{abstract}
This proposal takes into consideration three categories of unusual narrative, connected to human life - the invisible, the everyday and the unmentionable - often placed in the outer fringe of our attention or completely ignored.

The invisible: that which inhabits our world and often influences our lives, even though escaping our awareness, because active in dimensions that we cannot see or do not know to guess. The everyday: what accompanies us in every moment of our lives and that produces in us a habit that makes it obvious (and then again, but otherwise, invisible). The unmentionable: what happened at some time and somewhere, and the memory of which, for convenience, hypocrisy or convenience, has been removed or put on the edge of our life (and therefore to the visible limits),

These categories have been chosen as paradigmatic of new experiences on Cultural Preservation. The comprehension of the fundamental value of intangible cultural heritage, which came less than ten years ago to be part of the official definition of "museum" written by International Council of Museums, indeed, has opened new perspectives in the field of curating and exhibition design, often destabilizing and unexpectedly coincident. Therefore we needs updated languages, more interactive and interdisciplinary, towards the construction of a real design of the intangible cultures, able to reflect (and make reflect) on at first sight marginal phenomena, preserving their value of social and historical testimony and making it comprehensible to an audience as broad as possible. The new methods of staging these tales turn the apparent immateriality of knowledge of their socio-cultural values into occasion of development solutions, in form of exhibition design products and related services.
\end{abstract}


From the invisible, the everyday and the unmentionable towards narrative strategies to explain, understand, remember. New perspectives on cultural preservation.

\section{Introduction}

This proposal takes into consideration three categories of unusual narrative, connected to human life - the invisible, the everyday and the unmentionable - often placed in the outer fringe of our attention or completely ignored.

The invisible: that which inhabits our world and often influences our lives, even though escaping our awareness, because active in dimensions that we cannot see or do not know to guess.

The everyday: what accompanies us in every moment of our lives and that produces in us a habit that makes it obvious (and then again, but otherwise, invisible).

The unmentionable: what happened at some time and somewhere, and the memory of which, for convenience, hypocrisy or convenience, has been removed or put on the edge of our life (and therefore to the visible limits),

These categories have been chosen as paradigmatic of new experiences on Cultural Preservation. The comprehension of the fundamental value of intangible cultural heritage, which came less than ten years ago to be part of the official definition of "museum" written by ICOM (International Council of Museums), indeed, has opened new perspectives in the field of curating and exhibition design, often destabilizing and unexpectedly coincident.

«Cultural heritage does not only embrace the tangible expressions like monuments and objects throughout the years. It also includes the living expressions like the traditions that many groups and communities worldwide have been passed down by their ancestors and will continue to pass on to their descendants, mostly by word of mouth. Although it is the motor of cultural diversity, this heritage is fragile (...) Thus, ICOM commits itself to protecting the intangible heritage identifying and managing resources along with UNESCO who adopted in 2003, the Convention for the Safeguarding of the Intangible Cultural Heritage». (ICOM, 2016)

Therefore we needs updated languages, more interactive and interdisciplinary, towards the construction of a real design of the intangible cultures, able to reflect (and make reflect) on at first sight marginal phenomena, preserving their value of social and historical testimony and making it comprehensible to an audience as broad as possible. The new methods of staging these tales turn the apparent immateriality of knowledge of their socio-cultural values into occasion of development solutions, in form of exhibition design products and related services.

\section{The invisible. To show what is not visible}

The sight is the predominant human sense, especially in Western culture. Everything we are used to deal with daily, every situation, event, relationship is bound to the world of the "visible". One can say that all of us we all living in a globalized society where what we see has become what "is", in the sense of what real exist. Is not by chance that the sight supremacy is strongly connected with the fulfillment of our contemporary consumer society, totally linked to the aesthetic effect (and therefore "attractive", in terms of commercialization) of the image. Most of communicative and expressive media we got it, so, are designed precisely in relation of the attractive and persuasive force of the images. Nevertheless there is an hidden world which often totally escapes from our view and that, therefore, we ignore, taking it for granted, or eliminating it entirely from the horizon of our awareness.

It is the level of the invisible: a place that we are hardly able to define in terms of boundaries, size and appearance, but that inhabits our world and often influences our life, even though escaping to our 
conscience, because active in dimensions that we cannot see and could even guess. These parallel worlds, of which we are part, almost without realizing it, often are intangible places essential for our own physical survival. Bring them to the surface and make them accessible to all, is an innovative opportunity and a precious occasion to trigger new forms of storytelling, to accelerate processes of understanding whose effects go far beyond the cultural enrichment, involving issues such as the environment and its defense, the health, etc.

\subsection{The Keti Haliori World Water Museum project. A symbolic collection}

The World Water Museum project, made by the Greek artist Keti Haliori is an installation that «focuses to alert people on the challenges of clear, potable water on the planet. It approaches surrealistically the vast environmental problem, presenting water as museum item» as it is written in the Idea page of his website. (WWM, 2016)

It is important to note that although it is an art installation, its name includes the word "museum". A choice that testifies the intention to position itself as a narrative event with its own specific physicality and temporality (the project foresees its location in a permanent exhibition at a traditional house in the Greek island of Hydra and an never-ending development, across continuous donations from around the world). Keti Haliori chooses in fact, to deal with the water exactly as an evidence to be put on display into a museum, activating, in this way, its artistic and social value as a subject to be preserved and, above all, to be placed at the center of a different intellectual attention. The water, usually taken for granted and therefore underestimated or even ignored, becomes a complex narrative system that, through its own existence, is it told as a fundamental life element itself and, in perspective, an urgent and strategic global environmental problem. The development of the World Water Museum collection is based on the voluntary cooperation of anonymous people, who are asked to send samples of the waters of its rivers or lakes. A collective action that activates a partnership process and, therefore, a sense of belonging and that becomes immediately a metaphor of a global feeling to the problem that the availability of water resources presents to the whole planet, and to the risks of its forthcoming shortages. The water samples received in this way are submitted to chemical analysis, then classified and finally conserved in laboratory vessels, reporting the data of their origin and chemical composition.

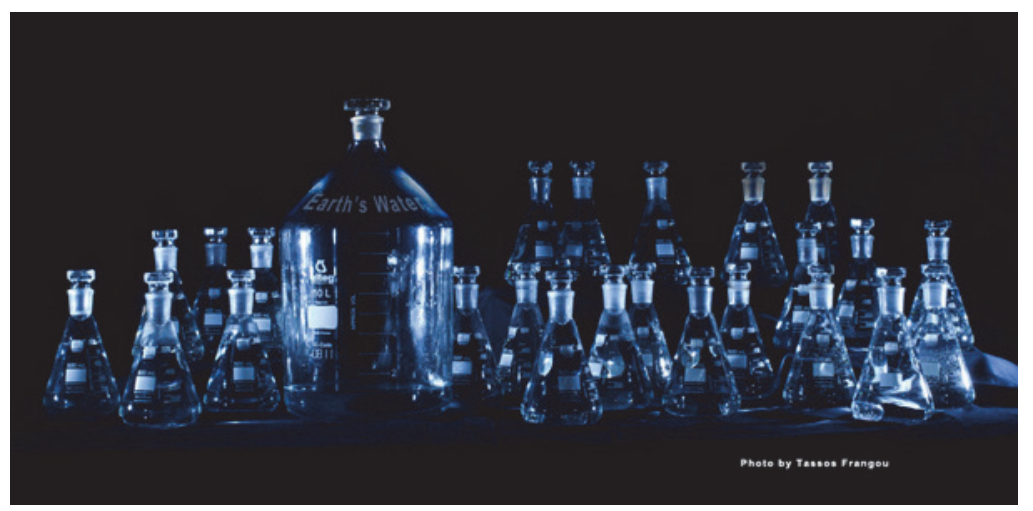

Fig. 1 World Water Museum, an installation by Keti Haliori. (Photo: Tassos Frangou; source: http://worldwatermuseum.com/index.html\#.VzCxtztf3IU)

Again, the meaning of the museum concept is well explained into the Idea website page: «The project does not carry out a factual scientific research of the condition of the world rivers or lakes water sources. 
From the invisible, the everyday and the unmentionable towards narrative strategies to explain, understand, remember. New perspectives on cultural preservation.

Its completion will constitute a symbolic collection of the samples of water which was conducted at an unspecified place and time, so that the present space-time picture of the river waters is presented whatever that may be - without the application of scientific criteria and selective procedures». (WWM, 2016) The main principle of this installation is to make clear something that is well rooted in the very nature of the subject of the story - the indispensability of water - but, at the same time, almost totally ignored. For this reason a small portion of $100 \mathrm{ml}$ of water for each sample received by the World Water Museum is mixed with portions of all the others, in a separate vessel called Earth water: a highly symbolic object, tangible icon idea of common belonging. The interaction of multiple communication levels and the presence of different degrees of conceptual and sensorial involvement require a redefinition of the real idea of content curatorship and of the expression modes implemented with its staging strategies, remodeled to make visible what really exists behind all obvious appearances of everyday. The World Water Museum is a potential structure of a "museum work in progress" through an art installation that, making the water something to collect, to classify and to exhibit, reveals, precisely with these actions, its social and cultural value.

Exactly the artistic point of view from which the project originates, a project which is not intended as a scientific research, but rather a symbolic collection, generates innovative points of view looking at water no longer as pure chemical element, but, rather, as an essential factor for understanding ethnographic, economic and political phenomena of the past, the present and the future. So the water becomes a material element that reveals multiple degrees of intuition about intangible factors linked to it: events which must be revealed with the development of innovative staging methodologies. The role of artistic intuition is essential, therefore, to activate new metaphors. Not by chance the work of Keti Haliori active dialogue with the German artist Uwe Laysiepen (better known as Ulay), whose magnum opus is the Earth Water Catalogue, «a growing archive, database, library and platform, be it online or in print, available from the very outset to any user or reader; artist, scientist, engineer, civil servant, scholar, student, or simply any water consumer». (EARTH WATER CATALOGUE, 2016) Synergies by Ulay+Keti Haliori, indeed, alongside Catalogue and Museum, amplifying the idea of water as a natural heritage of which we should fully perceive the substance and significance.

\subsection{Micropia, Amsterdam. Discovering the invisible life}

The willingness to make visible the invisible is the subject of the complex, innovative and surprising curatorial and staging project for the Micropia in Amsterdam, which lasted ten years. «This museum is about the invisible world, - says the museum's creator, Haig Balian - Two thirds of the natural world on this planet is invisible. One way of making it more visible is to imagine that every human being carries almost two kilograms of micro-organisms and bacteria. Half of the oxygen that we use is made of bacteria, and when you know that you have 10 times more micro-organisms in your body than body cells then you realize that you are a part of that invisible world». (EURONEWS, 2014) Realized nearby the Artis Royal Zoo, Micropia unveils the world of micro-nature, introducing a non-specialist audience, to the discovery of microbes: undetectable dimensions living creatures, yet present everywhere, since from our own body, in exponential amounts. An "other" living world surrounding us, of which we are part, but that we know little and that we usually remember only in relation to illness and todisease, but which, however, is essential for our survival. In order to make real and understandable this narrative of the invisible, a broad team of scientists and specialists worked together with the exhibition design experts of the Dutch architects office Kossmann.dejong, in close collaboration with ART+COM Studios, a Berlin-based media design firm. The narrative and staging structure of the museum exhibition is made by a series of multimedia installations that allow visitors to confront the world of micro-organisms according to a broad spectrum of activities, which involve them constantly: in this way are activated a series of experiences that make us understand what ourselves are part of this invisible world. 

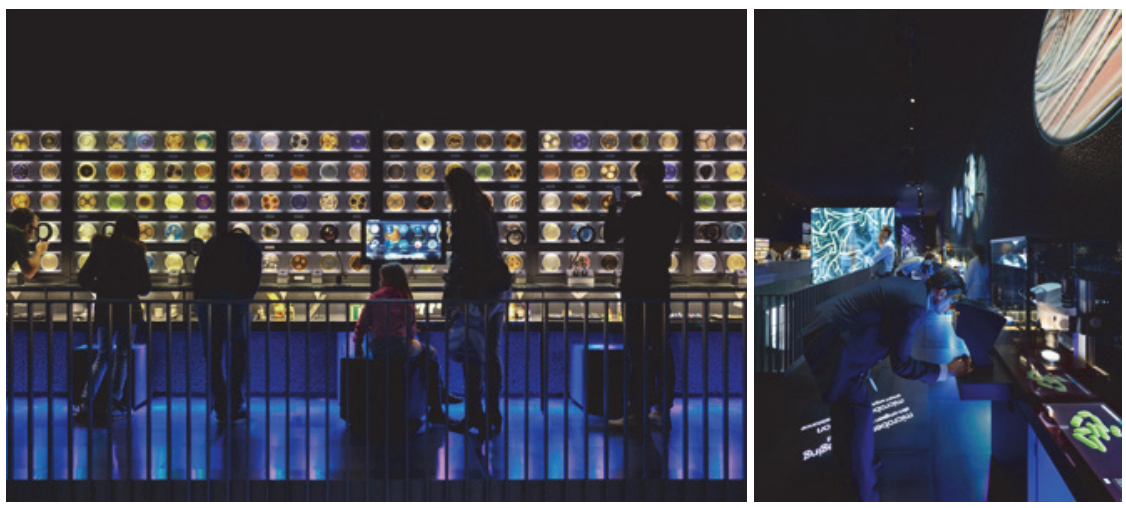

Fig. 2 Micropia, Amsterdam, The Netherlands. 2014. Source: https://artcom.de/en/project/micropia/

«We have aimed for a balance between experience and knowledge». (KOSSMANN.DEJONG, 2016) The museum works as a large laboratory which reveals the presence of microbes in all aspects of our lives: the discovery of a parallel world. Entire colonies of real microbes that dwell in large petri dishes (enlarged reproduction of the typical containers for laboratory bacterial cultures) can be viewed through microscopes connected to large TV screens, revealing iridescent geometries of these collections of living organisms: true works of abstract art created by nature itself. (Something that reminds to the experiments of artists such as the australian Peta Clancy or the austrian Sonja Bäumel)
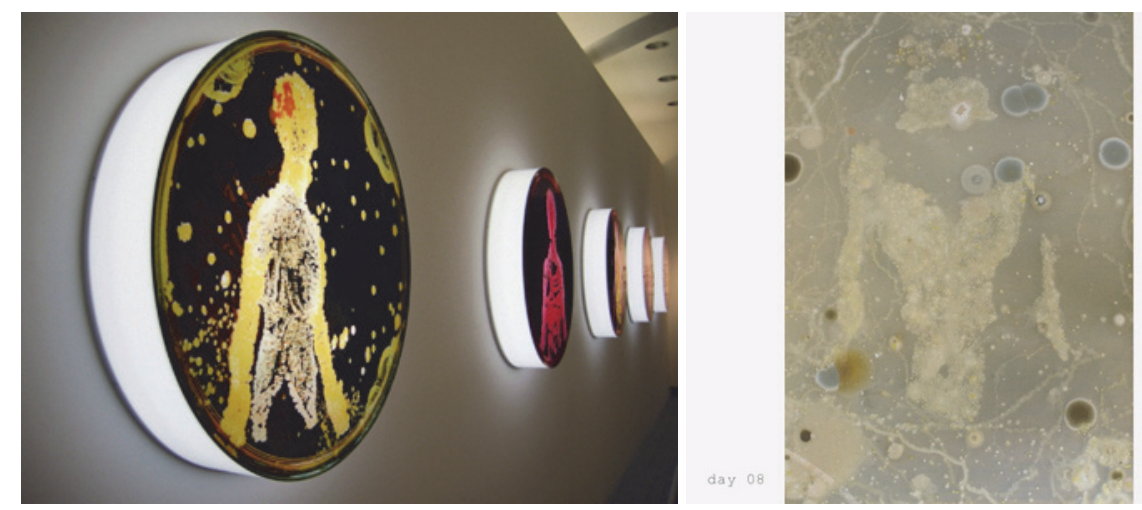

Fig. 3 Peta Clancy, “Visible Human Bodies", Australian Centre for Photography, Sydney, 2007. (Photo: Xain Milke; source: http://petaclancy.com/works/?pid=61)

Fig. 4 Sonja Bäumel, Oversized Petri Dish "Self-initiate", 2009. (source: http://www.sonjabaeumel.at/work/bacteria/oversizedpetri-dish)

To tell the unsuspected symbiosis that characterizes the life of people and microbes is it possible to perform direct experiences by interacting, for example, with a full body scanner that lets you view where and how many microbes "are resident" on your body, or dealing with the "Kiss-o-Meter" to find out how many of them are exchanged during a kiss. The narrative space of the museum is therefore rewritten through the intertwining and mutual contribution of different disciplines, aimed at the script of actions, both in their uniqueness that in their sum, draw new boundaries of the exhibition design concept. 

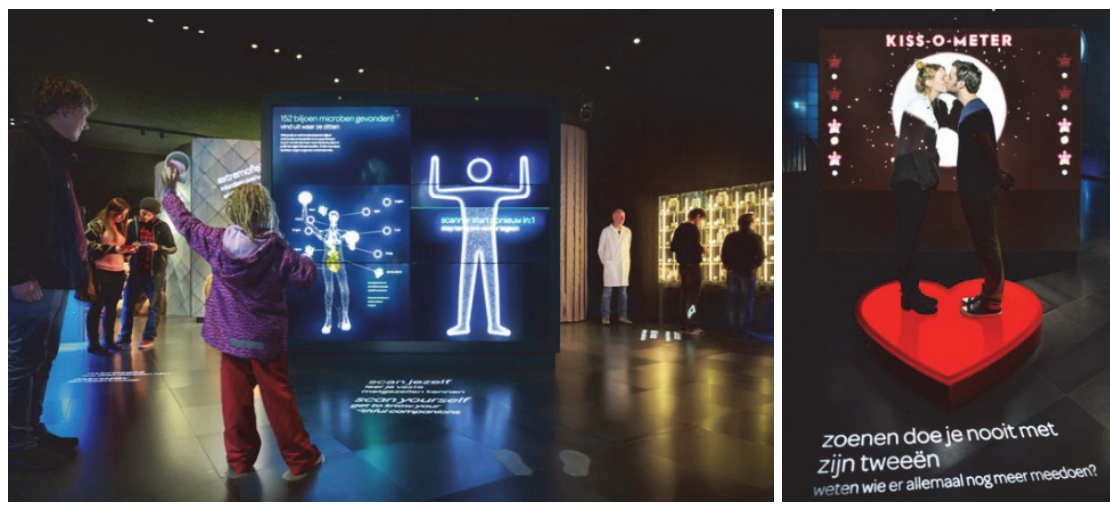

Fig. 5 Micropia, Amsterdam, The Netherlands. 2014

(source: https://artcom.de/en/project/micropia/)

«The mission of Natura Artis Magistra is to help a wide public discover and experience the interconnectivity of life and nature and to encourage the love of and concern for the natural world. This objective is of vital importance to our civilization: we cannot understand human identity without grasping how nature and human civilization are fundamentally bound up in and dependent on each other. It is impossible to fully understand the interconnectivity of the natural world without knowledge of the most powerful, most successful and, at the same time, the smallest life form: micro-organisms». (MICROPIA, 2016) Micropia is the "zoo of microbes", where narrow cages and fake scenography are replaced by the interaction and the stimulation to explore, triggered by intelligent and innovative paths of exploration. The design project exceeds the boundaries of mere exposition and become the scope of application of a systemic design, including the development of alternative mode of interaction with science, by the design concept of a media-based exhibits as well as their interaction and hardware design, prototyping and programming.

\section{The everyday: the usual is not obvious}

How many things happen in everyday life of each of us? And how many of them really affect our personal history? Surely everyone can subjectively respond to both questions. But if these events certainly important, but so strictly personal, hides, embedded, histories whose evocative power was so strong to take a universal value: pictures of a global story that involves us all? Recurring events, common needs and requirements, moments of joy and drama: does exist a cross-syntax that brings us closer each other by sharing similar experiences?

The idea that there are social and cultural heritages that, despite the great differences that characterize contemporary society, got common matrix - an intuition that has his most interesting definitions in the principle of collective memory formulated in the early twentieth Century by Maurice Halbwachs (HALBWACHS, 1925) It is now also widespread in museum design, generating ecological principles of the alternative culture. These principles raise everyday life to a privileged place of exploration and understanding of social phenomena that we have gone through and that surround us today, defining an aesthetics of everyday where the usual is no longer synonym of obvious. The Halbwachs hypothesis, in brief, states that is the collective memory that allows the constitution of an individual memory (not the other way) and thus our memories are set up in accordance of its membership of a social group. As a 
result the value we attribute to them individually is such as and is changeable in time, because its being closely tied to changes in the common social judgments. The combination of the traces of the past that a social group maintains, develops and transmits from one generation to the next, could be understood and represented through objects, images and habits of different historical periods and in relation to trends and traditions with which they took shape and became consolidated.

\subsection{Tidens Samling - The Museum of Everyday Life. Please touch the objects}

In this sense is paradigmatic the Tidens Samling - Museum of Everyday Life in the 20th Century of Odense (Denmark) that exist since 1992 defining itself the first "hands-on" museum of cultural history in Denmark. Indeed, the museum includes a large collection of objects (furniture, clothing, toys, magazines, records, etc.) that have been of common use in Denmark between 1900 and 1980. This heterogeneous collection is set within eight full-scale domestic environments, whose original interior shows its normal location in the daily life of typical Danish houses of the time. The most interesting feature of this museum, which otherwise would be very similar to a memorabilia store, is that visitors can and should interact with the environments and objects. "Our guests are welcome to make themselves at home in the living rooms where they may sit down, open the drawers, read the books, and put on music». (VISIT DENMARK, 2016) The narrative of the museum is no more static: the interaction exceeds the classic "do not touch" taboo and defines new rules of belonging between visitor and objects on display. The classic period rooms evolves themself from scenic settings full of objects, into places of direct experience.
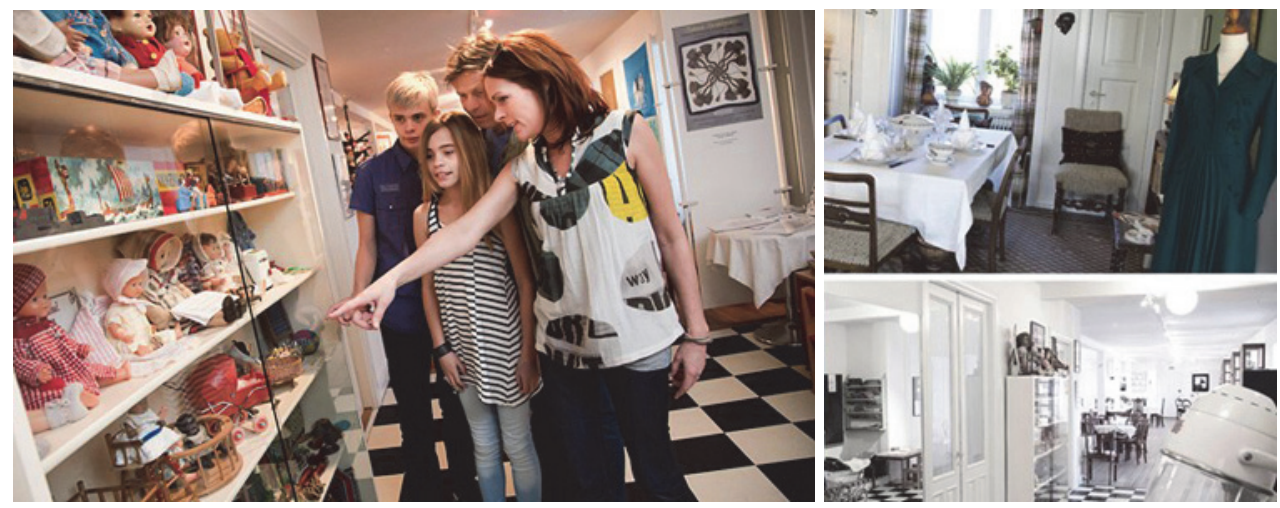

Fig. 6 Tidens Samling - Museum of Everyday Life, Odense, Denmark. 1992

(source: http://www.visitdenmark.pl/pl/denmark/tidens-samling-museum-everyday-life-20th-century-gdk613063)

At Tidens Samling you can sit down on furniture and you can try the clothes becoming part of the collection itself: all senses are involved in a time travel made in first person and without digital artifacts: the relationship is immediate, tangible, and tactile. «Tidens Samling is a place for all generations to meet and exchange memories and rediscover the history of your parents, grandparents and great-grandparent's childhood. The many details give recollection of early childhood for the elderly, whilst children and young people can learn about the lives of past generations». (TIDENS SAMLING, 2016)

\subsection{Gli oggetti ci parlanno, Reggio Emilia, 2012. Let's listen}

The placement of everyday objects in museum facilities like the Tidens Samling always generates a destabilizing effect because these objects are not artworks "unique" as masterpieces and so they are not 
From the invisible, the everyday and the unmentionable towards narrative strategies to explain, understand, remember. New perspectives on cultural preservation.

included into a critical point of view which recognizes them an aura and, moreover, it doesn't matter their scientific-technological aspect (which is competence of the collections of scientific museums): their real nature is uncertain and hardly to define. Are they purely worthless consumer items (and therefore not worthy of museum location) or silent witnesses of different narrative structures: clues able to define different perspectives of exploration and knowledge of the multiple mix of stories that constitute the deepest sediment upon which the History (with capital first letter) can build itself?

The laboratory Gli oggetti ci parlanno, curated by by Italian architect Italo Rota in 2012 at the Chiotri di San Pietro in Reggio Emilia, as part of the exhibition Lavori in corso had launched a call for all citizens to bring to the Musei Civici of "Palazzo di San Francesco" objects common belonged to them and from them recognized as emblematic of some of the recent past living conditions. «Objects related to their memory but chosen with a critical act giving priority to those which in their time have meant a breakthrough, a turning point, a change» (FOTOGRAFIA EUROPEA, 2016) The initiative meant to experiment participatory cooperation methods to increase the second half Twentieth Century period room collections of the museum, through an act of shared reflection about the past and future of our community. Means brought to the museum by common people were photographed, cataloged and displayed with a temporary borrowing arrangements, just as real artworks. The idea of the exhibition, open to criticism for its aesthetic results and for a certain complacency in the accumulation excess, had its own clarity of purpose: to outline an insight into the social history of the Italian post-war period, through a visual proposition of daily life, urging a reflection on some open issues about the future.

The possibility of this principle to be applied to the original collections of the Reggio Emilia Musei Civici, hybridizing historic objects and documents to other more anonymous origin has raised great controversy at the time. An exhibition defined by multiple assembly and free association that, for many critics of the operation, if brought within the permanently collection would have subverted the philological conservation duty that is intrinsically linked to the role of the museum. An issue that certainly must be analytically dealt in the next years and which can be solve in the development of new types of professional designers of integrated system involving conservation, curation, communication and staging.
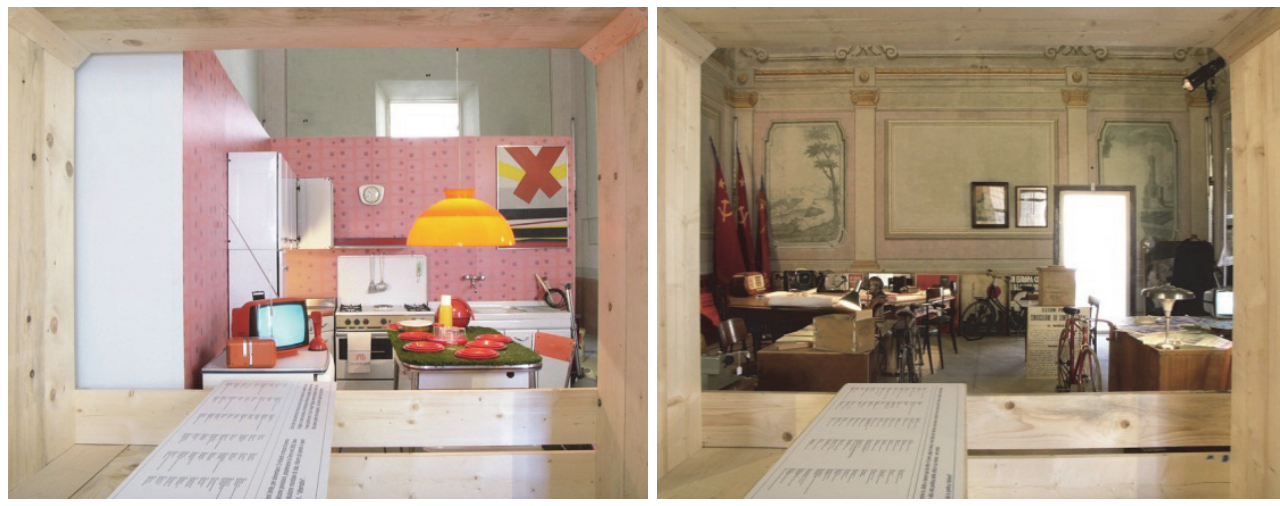

Fig. 7 Gli oggetti ci parlanno, Reggio Emilia, 2012. Source: courtesy of Studio Italo Rota \& Partners

\subsection{The Museum of Broken Relationships by Vištica and Grubišić}

If the daily tracks are not included into a consolidated display structure and into a historical context and built, however, the unique and original core, as happens for the Museum of Broken Relationships, founded 
by Croatian artists Olinka Vištica and Dražen Grubišić, a highly poetic and compelling vision invests banal and anonymous objects inventing a museum that, for its originality, was awarded in 2011 for its capacity to be innovative, challenging the common perception of the role of museums in contemporary society.

«The Museum of Broken Relationships encourages discussion and reflection not only on the fragility of human relationships but also on the political, social and cultural circumstances surrounding the stories being told. The museum respects the audience capacity for understanding wider historical, social issues inherent to different cultures and identities and provides a catharsis for donors on a more personal level». (MUSEUM OF BROKEN RELATIONSHIPS, 2016)

The Museum of Broken Relationships comes from the intuition that the drama of the end of a love is a traumatic moment in people's lives, and that this event is universal: everyone, sooner or later got to facing it, no matter the age, religion, culture or geographical origin. The devastating power that this event generates can radically change our lives and often leaves a residue of intense and mixed feelings: sadness, hopelessness, anger, revenge, apathy...

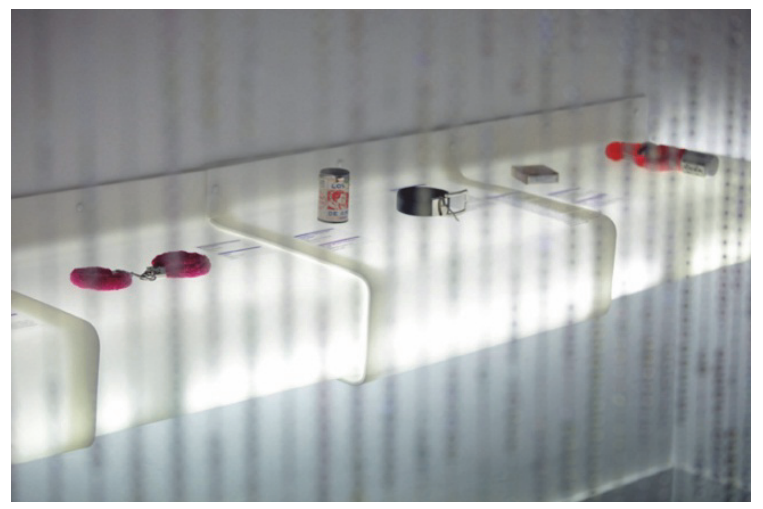

Fig. 8, Museum of Broken Relationships, Zagreb, Croazia, 2007. Source: https://brokenships.com/en/about/download

The visitor goes to Museum of Broken Relationships not only to view the collection on display, but to find himself and their common experiences, observing everyday objects of little value, sometimes surprisingly ugly, but that find sense, despite their apparent randomness, in their common emotional origin, creating a universal feelings portrait, unexpectedly logical and understandable.

\subsection{The Museum of Obsolete Objects by Jung von Matt}

Everything can be narrated. What really makes interesting a storytelling is its skills to be highly original in capturing an unexpected point of view, even when dealing with a topic seemingly trivial. There are many factors that contribute to the achievement of this result: intuition and practice to the originality, intelligence and earnestness in the construction of the narrative, clearly the motives and purposes of the narrative itself. As part of the cultural preservation idea this means above all to know how to identify events marginal at first sight, a hidden dimension, that makes them key witnesses of widespread social phenomena, affecting the reality of our lives, determining it logical structure, and changes. A sensibility that identifies the intangible culture, which nestles in the marginal phenomena and makes it understandable to everyone. Then that's also a project with an extremely simple structure becomes a valuable tool for understanding complex and broad phenomena. Imagine all the objects that lie abandoned in the bottom of our homes drawers, because displaced by new technologies that have made 
From the invisible, the everyday and the unmentionable towards narrative strategies to explain, understand, remember. New perspectives on cultural preservation.

them useless. Their destiny is most likely the dump; the lucky ones, perhaps, will end up in some modern antiques market, waiting for some nostalgic. They are the "obsolete objects", in the moment of their maximum glory desired and everywhere widespread and now totally abandoned.

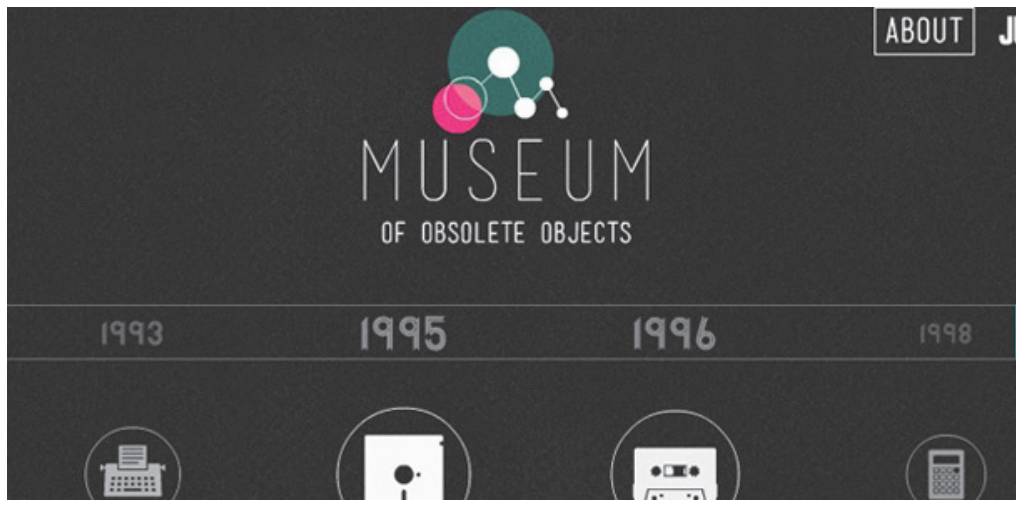

Fig. 9, The Museum of Obsolete Objects by Jung von Matt. Source: http://projects.jvm.com/mooo/?lang=en\&hl=en_US

Nevertheless behind their aging you can outlining uses and customs of ages also right next door to us and, above all, one can become aware of how quickly, often secretly driven by the so-called "market laws" have changed the way we live. Above all, we can realize how contemporary society, so strongly influenced by technological advances, produces and consumes objects (and the related mass culture), that once lasted for generations and today, in a few years, appears to the youngest already unknown and incomprehensible. These are the multiple narrative structures that trigger with a visit to a virtual museum, which only exists in the web (although lately has generated many attempts to "real" copies): the Museum of obsolete objects designed by the German advertising agency Jung von Matt.

Made up of a You Tube channel (http://projects.jvm.com/mooo/?lang=en\&hl=en_US) the museum displays, in fact, many objects that have accompanied our most recent history (rotary telephone, floppy disc, phonograph, compact audio cassette, etc.) organizing them, with elegance and irony, in short video clips that, like real tutorial of social archeology, identifying along an interactive time line the year of "birth" and that of obsolescence. Then it is explain how these objects works by a voice over, with metal intonation, which reinforces the impression to be time travelers who have discovered something very ancient, forgotten in who knows which computer archive. «Although a digital replacement has been found for all these analogue tasks the carms of the originals can never be replaced. Thus we have created the Museum of Obsolete Objects to house and exhibit those fading memories, not only, to jog our against brain, but to also show future generations the lost technological marvels of the 20th century» (JVM, 2016)

\section{The unmentionable. Nothing should be forgotten}

Since a few decades by now, on the international scene, does exist many museums devoted to events the memory and experiences of which many people, perhaps, would prefer to let disappear silently, in reason of an ambiguous sense of removal. They are places, in fact, that preserve the memory of tragic events because, aware of their ethical and social value, would transform the telling of those events into moments of deep reflection, awareness of conquest. Here on tries to make visible and above all understandable the trauma, the dramatic event, activating ways and narrative instruments to help the museum to be a vehicle 
for memory and not memory itself. This is an highest importance critical point: the museum does not should identify itself with the memory the things, but needs to be the place that triggers the memory, helping the story of the past to get in tune with the contemporaneity, to evoke the experiences past and make them the object of reflection in the present. The museum is not memory itself: it is opposition to memory loss. Taking care of what is unmentionable, what has been removed (and then rejected) and placed at the edge of our lives, these museum act as places where the dramatic dimension is not simply repeated, but rather faced and understood. A complex mission that requires the ability to apply to contemporary society, made up of multiple and different memories and perceptions that must find space for the emergence of a renewed sensitivity.

\subsection{The Museo Memoria y Tolerancia, Mexico City.}

When someone think about something unmentionable, inevitably, the first thought goes to the large quantity episodes of insane collective violence who have gone through the human history without interruption, in every time, place, and culture. If the two great World War (especially the Second one, indelibly spotted by nazi war crimes) are the most documented moments of this story of the "unmentionable", this should not obscure the many other slaughters perpetrated in the world in the name of false ideals and real racism or deviant ideologies. Paradigmatic in that sense, is the recent Memory y Tolerancia Museum of Mexico City, designed by Arditti + RDT Arquitectos. Here, in fact, the theme of memory moves from the Holocaust, and then introduce the principle of Genocide and Crimes against Humanity defined by the UN in 1948 and continue the journey into the abyss of the Armenian slaughters, ex Yugoslavia, the Rwanda, Cambodia, Guatemala, Darfur. Every genocide is there, with its macabre load of blood, with the images the executioners and the victims, with the symbols of propaganda and the weapons of mass destruction. With names, portraits, crosses. Every continent bears his sad contribution. no one can feel itself "excluded".
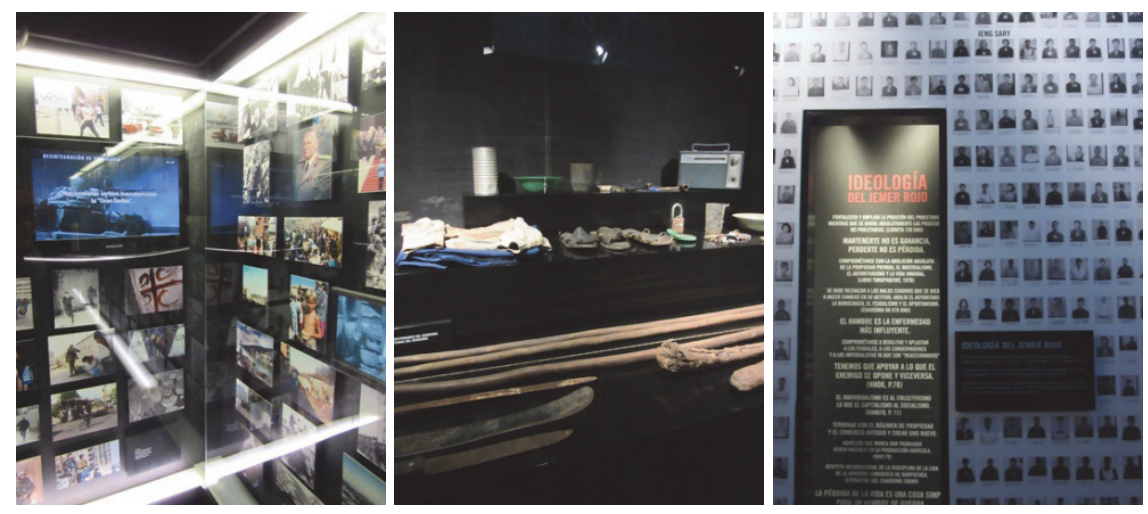

Fig. 10, The Museo Memoria y Tolerancia, Mexico City, Mexico, 2011 (Photo: Marco Borsotti)

« (...) every crime is different, while each genocide also refers us to an idea of unity, as if it too were part of a single immense night. It unfurls itself with a systematic, logical and inhuman nature, leaving behind it a sensation that takes us back to a single and selfsame monstrosity. Each genocide endorses the next; each mass-murder on this scale - replete with evidence and proof - justifies all the others of the same order. The Nazi executioner is complicit with the stalinist torturer, the Rwandan killer answers to the Serbian assassin, in full complicity». (OLLÈ-LAPRUNE, 2011) 
From the invisible, the everyday and the unmentionable towards narrative strategies to explain, understand, remember. New perspectives on cultural preservation.
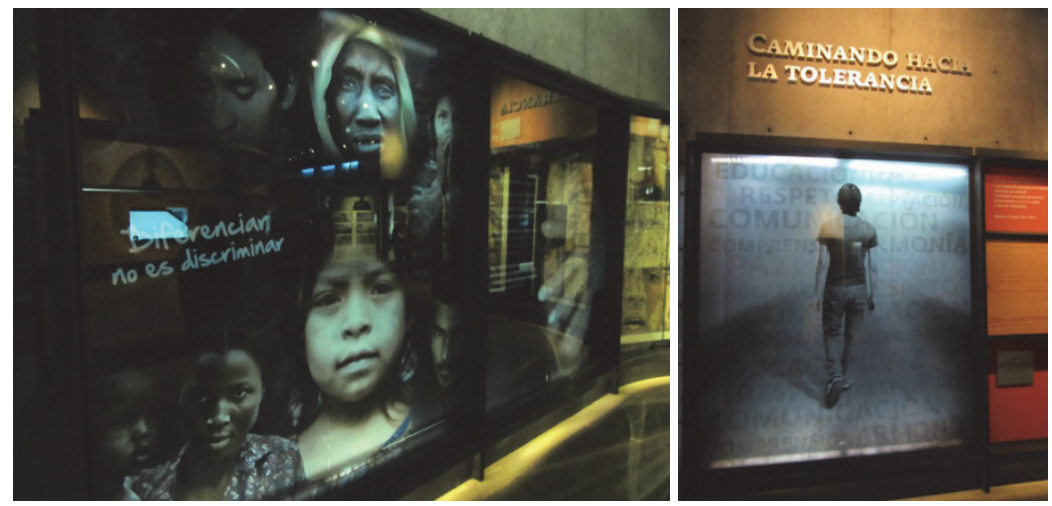

Fig. 11, The Museo Memoria y Tolerancia, Mexico City, Mexico, 2011 (Photo: Marco Borsotti)

The museum's curators have brought the theme of memory to the house of each of us, making it a common duty and to do that they asked to the exhibition project to support different narratives that combine faces, phrases and objects of the killers and the victims in a shocking continuity. The museum introduces, however, also the theme of tolerance, which closes the exhibit as a light at the end of the tunnel. The narrative structure here does not indulge, however, into a too easy optimism: it recalls, instead, issues such as gender equality and the freedom of expression, culture, religion. A narrative that does not hide affirms or imposes: shows reveals, and ask willingness to consciousness.

«A museum is by definition tied to the past, setting out themes that clarify our present in the light of recent or distant experiences. From far off, the participants in appalling tragedies call to us; paths are to be found for new reflection that tells us how to envisage this relationship between the practice of the word and the rejection of the silence that accompany genocides». (OLLÈ-LAPRUNE, 2011a)

\subsection{The Museo Laboratorio della Mente, Roma.}

There are many narratives that we usually put on the borders of our consciousness and over. Events, places, people that we addresses more or less consciously to oblivion and which we does not even allow the consolation of a minimum act of memory. This absence of memory, often unconscious, but collective, is not linked only to the issues of violence more evident, than that which builds the History (again with a capital letter): often involves although apparently minor events, related to marginal conditions, which the current logic of the so-called "right-minded society" does not accept because far from usual canons of understanding. They are the border places where marginalization, ignorance, non-knowledge is limited and tolerated in reason of a sort of social contract of not visibility.
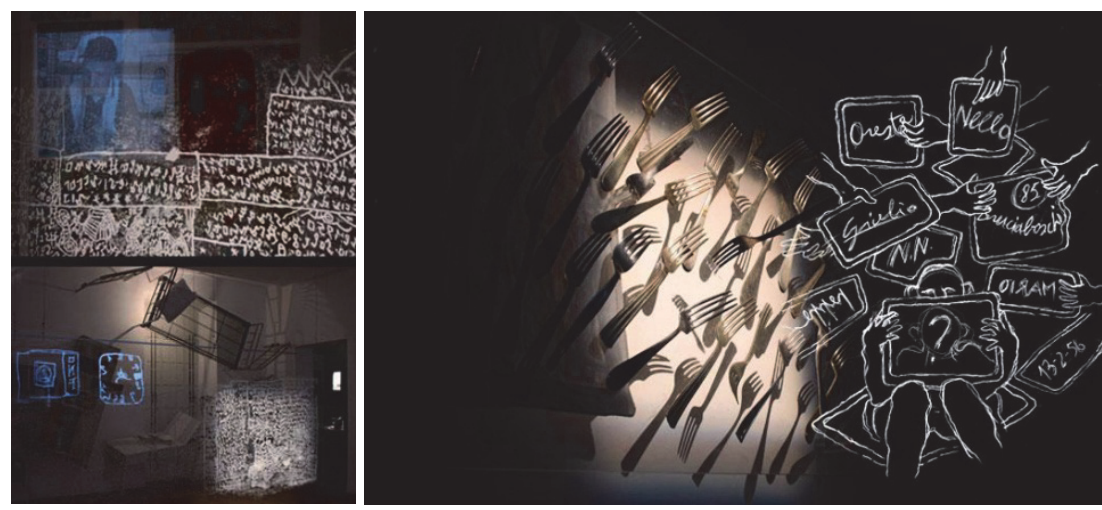
Fig. 12, The Museo Laboratorio della Mente, Roma, Italy, 2008 (Source:http://www.studioazzurro.com/index.php?com_works)

Unveil their presence therefore becomes a necessary and courageous civil act, but is often also an opportunity to discover a different humanity, rich of important values, engaging stories, and of real things that time changes, redesigns, makes comprehensible. In Rome, the project Museo Laboratorio della Mente, created by UOS Studies and Research Centre ASL Roma E and Studio Azzurro, revealed, through interactive video installations that wholly involve the visitor, the world of mental illness, just where this was placed and hidden from the world. It faces the hard historical truth, but also the scientific and social progress, culminating in Italy with a legislative reform that closed definitively the asylums (Law Basaglia, 1978) and especially reveals a large portrait of a forgotten humanity. The museum tries to define new communication contexts capable of give visibility to a lot of stories hidden behind the mental problems, starting from the limitations of physical freedom and the psychological constraints, up to clinical practices to contain first and then openness and understanding. But also the humanity of every day, the fears and the hopes, the unexpected and valuable poetic and artistic force of some "guests."

«The Museo Laboratorio della Mente was founded with the clear intention to build communicative contexts that favor the promotion/prevention of mental health through active and meaningful participation of the visitor. Within a narrative inspired by a multi-textuality and a continuous oscillation between real elements and laboratory experiments (...) the visitor is invited to reflect on social exclusion paths and to change/rethink its attitude towards diversity». (MARTELLI, 2010)

Visitors thus perform a profound learning experience, observing and listening to the witnesses of what was a parallel underwater world, dividing the attention to the narratives provided by the exhibiotio project with the space itself, which is the original one, which gradually takes possession of them, bringing people in a total immersive situation. A condition created to arise interpretation processes that lead to a conscious inner public growth.

\section{Conclusion}

All these innovative scenarios of exhibition designs require training of new professional figures related to the design, management and development of new products cultural, communication and technology through innovative forms of knowledge management by the continuous development of models, tools and systemic modeling based applications. so complex narrative structures requiring simultaneous management of multiple design disciplines, combined with a strong sensitivity to get in tune with the cultural and scientific content defined for the museum. In this sense, the system design and is housed in its logical and complete fulfillment.

\section{References}

EARTH WATER CATALOGUE. <http://www.earthwatercatalogue.net/about> [See: 8 May 2016]

EURONEWS. Sci-tech science. (2014) <http://www.euronews.com/2014/10/06/step-inside-the-micropia-zoo-to-seethe-invisible-world-of-microbes/> [See: 8 May 2016]

FOTOGRAFIA EUROPEA. Gli oggetti ci parlano/Lavori in corso <http://www.fotografiaeuropea.it/lavori-in-corso/> [See: 10 may 2016]

ICOM. THE WORLD MUSEUM COMMUNITY. <http://icom.museum/programmes/intangible-heritage/> [See: 8 May 2016]

HALBWACHS M. (1925) The cadres sociaux de la mémoire. Alcan: Paris

KOSSMANN.DEJONG. <http://www.kossmanndejong.nl/project/micropia-artis/> [See: 10 may 2016] 
From the invisible, the everyday and the unmentionable towards narrative strategies to explain, understand, remember. New perspectives on cultural preservation.

JVM. Projects $<$ http://projects.jvm.com/mooo/?lang=en\&hl=en_US $>$ [See: 8 May 2016]

MICROPIA. <http://www.micropia.nl/en/about-us/mission/> [See: 10 may 2016]

MUSEUM OF BROKEN RELATIONSHIPS

$<$ https://brokenships.com/en/news/we_won_emf_kenneth_hudson_award_2011> [See: 10 may 2016]

OLLE-LAPRUNE, P. (2011). "Writing: rejecting the silence" in AA. VV. Museo Memoria y Tolerancia. Mexico: Arquine, p. 10

OLLE-LAPRUNE, P. (2011a). "Writing: rejecting the silence" in AA. VV. Museo Memoria y Tolerancia. Mexico: Arquine, p. 16-18

TIDENS SAMLING. The Permanent Exhibition. <http://tidenssamling.dk/exhibitions/> [See: 10 may 2016]

VISIT DENMARK. The official tourist site. <http://www.visitdenmark.pl/pl/denmark/tidens-samling-museumeveryday-life-20th-century-gdk613063> [See: 10 may 2016]

WWM. WORLD WATER MUSEUM. <http://worldwatermuseum.com/about.html> [See: 8 May 2016] 